\title{
DEVELOPING CHARACTERISTICS AND COMPETENCES OF A HEALTH CARE MANAGER: LITERATURE REVIEW
}

Nikita A. Sokolov, Vladimir A. Reshetnikov, Valeriy N. Tregubov, Olga S. Sadkovaya, Maria S. Mikerova, Dmitry A. Drobyshev Department of Public Health, Sechenov University I.M. First Moscow State Medical University of the Ministry of Health of the Russian Federation, Moscow, Russia

\section{RAZVOJ KARAKTERISTIKA I KOMPETENCIJA MENADŽERA U ZDRA VSTVU: PREGLED LITERATURE}

Nikita A. Sokolov, Vladimir A. Rešetnikov, Valerij N. Tregubov, Olga S. Sadkovaja, Maria S. Mikerova, Dmitry A. Drobyšev Odsek za javno zdravlje, Univerzitet Sečenov, Prvi moskovski medicinski fakultet, Moskva, Rusija

\begin{abstract}
Broadly educated professionals are a rely valuable resource for the Russian public health system in the current socio-economic conditions. Their capability to flexibly switch the focus and content of their activities in the changing and challenging environment is essential for successful performance.

The purpose of our study is to analyze the international evidence on managing the process of competencies' development in healthcare managers.

Competence-oriented education and training of future healthcare managers is of special interest. In light of this, the study of international data on the organization of the processes of key competence development is important. Here with, it is necessary to take into account the content of the studies, resources and technologies, factors that influence on this process, the development and evaluation of models aimed at improvement of the education of healthcare management professionals at medical schools.

We believe that the results of this review will help to develop and offer a number of practical steps aimed at optimizing the education and training of healthcare managers. In addition to a review of international data, this article presents an innovative project for the development of professional competencies of health managers - the Academy of Talent Development in Healthcare (ATDH). This project involves students of the Sechenov University who want to learn how to lead healthcare teams efficiently.
\end{abstract}

Keywords: Healthcare managers, public health, leadership, management competences, medical education.

\section{SAŽETAK}

Šroko obrazovani profesionalci su dragocen resurs za ruski javni zdravstveni sistem u trenutnim socio-ekonomskim uslovima. Njihova sposobnost da fleksibilno promene fokus i sadržaj svojih aktivnosti u promenjivom i izazovnom okruženju je neophodna za uspešan rad. Svrha naše studije je da analizira međunarodne dokaze o upravljanju procesom razvoja kompetencija kod menadžera u zdravstvu.

Posebno je interesantno obrazovanje $i$ obuka budućih zdravstvenih menadžera orijentisanih na kompetencije. U tom smislu, važno je proučavanje međunarodnih podataka o organizaciji procesa razvoja ključnih kompetencija. Pri tome je neophodno uzeti u obzir sadržaj studija, resursa i tehnologija, faktore koji utiču na ovaj proces, razvoj $i$ evaluaciju modela koji imaju za cilj poboljšanje obrazovanja stručnjaka zdravstvenog menadžmenta u medicinskim školama.

Verujemo da će rezultati ovog pregleda pomoći da se razvije $i$ ponudi niz praktičnih koraka usmerenih ka optimizaciji obrazovanja i obuke menadžera zdravstva. Pored pregleda međunarodnih podataka, ovaj članak predstavlja inovativni projekat za razvoj profesionalnih kompetencija zdravstvenih menadžera-Akademije za razvoj talenata u zdravstvu (ART). Ovaj projekat uključuje studente Univerziteta Sečenov koji žele da nauče kako da efikasno vode zdravstvene timove u svojim ustanovama.

Ključne reči: Menadžeri u zdravstvu, javno zdravlje, liderstvo, kompetencije menadžmenta, medicinsko obrazovanje. 


\section{INRODUCTION}

Broadly educated professionals are a rely valuable resource for the Russian public health system in the current socio-economic conditions. Their capability to flexibly switch the focus and content of their activities in the changing and challenging environment is essential for successful performance (1-3). In this regard, the selection and placement of personnel should be carried out with particular carefulness. Both their special training in public health and healthcare management and their general level of skills must be at high level. These professionals must possess the necessary skills and competencies in their chosen professional field $(2,4)$.

As it often happens, the inexperienced specialists, having rather a vague idea about the organization of health care, are appointed as the heads of facilities, including positions of chief doctors of hospitals and out-patient clinics. Here with a lack of clear confidence in the properly chosen professional pathway of healthcare managers leads to the situation that even the healthcare managers with significant administrative experience prefer to see themselves rather as clinical specialists (physicians, surgeons, etc.), but not healthcare managers. At the same time, it was found that the higher the administrative position is, the larger is the number of administrative functions to perform, compared to the number of clinical functions. The results from a study on the job satisfaction in healthcare managers demonstrate that the reasons for low satisfaction often lie in their own inability to organize their work and activities of subordinates, as well as in the lack of systematic approach to performance arrangement (3-5).

Certainly, a combination of specific training in management and working experience is needed to improve the quality of performance of the healthcare managers Therefore, an increase in the quality of education of the future healthcare managers is required for performance of the management functions in their future professional activity $(2,4)$.

In light of the above, the analysis of the international data on the development of the skills required for the effective implementation of administrative functions in health care organization is of interest.

The analysis of international data led us to the need of a complete modification of training for health managers that meets the long-term health system requirements. That is why we set up an innovation training program for healthcare managers at Sechenov University, which includes extensive use of active learning methods such as educational games, trainings, case studies, round-table discussions, master classes, mass open online courses, project development, training videos and many others modern educational approaches.

\section{Objective of the study}

The purpose of our study is to analyze the international literature on managing the process of competencies development in health care managers.

\section{Current health care system}

From the 90s, along with increasing requirements for higher professional education, the paradigm of achieving the outcome of the educational process has changed. The transition to student-centered education enhances the interaction between education and culture, and the culture plays a role of essential prerequisite for the realization of the creative potential of a person, which determines the inclusion in the educational process of the so-called culture-based technologies $(2,5)$. Today, most experts consider that besides purely professional knowledge and skills the university graduate should be able to apply practically, the graduate should also have the appropriate personality traits, developed cognitive, emotional and axiological spheres $(1,3,6)$.

Some authors point out the conflicts in the modern Russian educational system, between:

- the university educational outcomes and the needs of the labor market;

- the declared humanistic nature of education and the real image of a graduate;

- the integrative nature of the activities of the future graduate and ineffective teaching methods;

a desire to create a joint educational space with other (mostly European) countries and the reluctance of the Russian higher education to take into account emerging global trends in education $(3,8)$.

The most important survey on this problem was conducted by prof. Starodubov V. in 2014 (45) in Russia. The survey covered 33000 healthcare managers in the Russian Healthcare (HC) sector. The survey results demonstrate that there is an equal chance to meet a male or female in this professional field. They are rather young with the average age of 49 . Most of them work for more than 10 years as administrators. If we take a look at their educational background, we can see that they all are medical doctors and $1 / 3$ of them have not been trained in healthcare management. $22 \%$ of $\mathrm{HC}$ managers have got an additional degree either in management, economics, or law and psychology. Russian $\mathrm{HC}$ managers have rich working experience, but they are not aware of modern management skills and technologies. They rely mainly on their personal qualities and try to avoid risky decisions.

Also, we can see that almost $40 \%$ of HC managers in Russia came to work at their position by chance. About $28 \%$ were promoted by the personal pool and 33\% managers had in their career plan. Our recent retrospective study (50) has discovered that only $7 \%$ of healthcare managers had decided upon their future specialization at the University, $20 \%-3$ years following the graduation and $73 \%$ - had chosen this career even later. It is an interesting fact that generally $95 \%$ of students make the decision on the specialization either in therapy or in surgery in early years at medical schools. Currently, most medical public organizations are managed by doctors, who started their career 
as clinicians and were promoted to the top administrative positions.

But, in most cases, these people have no special knowledge and competences in management. The most common solutions are suggested by introduction of master's programs in healthcare management available to students with non-medical background.

The programs should be competency-based and provide knowledge, skills and characteristics.

The competency-based approach to training healthcare professionals consists of 5 main blocks:

The $1^{\text {st }}$ block is professional skills, combined with professional and social responsibility and personal engagement in continuing professional development.

The $2^{\text {nd }}$ block is the knowledge of a health system, patients' needs and human resources, understanding the environment of the organization and individual contribution of a specialist.

The $3^{\text {rd }}$ block is business administration which includes strategic, financial and general management, risk management, HR management and quality assurance.

The $4^{\text {th }}$ block covers communication skills, including partnerships and negotiations.

The $5^{\text {th }}$ block - Leadership is formed by the ability to translate the vision, influence and involve people and build attitudes. tion

The strategy of modernization of modern higher educa-

Because of the changed requirements of vocational training and social maturity of university graduates, many experts consider the need to improve the educational process for the purpose of its orientation towards the maximum realization of the creative potential of the student and the development of the student motivation towards further self-development. Therefore, the strategy of modernization of modern higher education is based on the introduction of competency-based approach, which is now recognized as one of the most promising approaches to the modernization of the educational process (5-8). This approach aims at the developing student knowledge and skills, as well as a number of key competencies in intellectual, communication, information and other areas $(3,8)$. In accordance with this set, the structuring of the learning process must be carried out, which will allow students to be able to effectively master these competencies during education.

Currently, most researchers consider the competencybased approach as the most important way of solving the challenges facing the entire sector of education, believing that its implementation should provide influx of competitive special- ists and thus contribute to the economic development of the country, promote the social and labor adaptation of youth, maintain Russian scientific and educational potential and the enhance international cooperation prospects $(2,5,7,8)$.

Analysis of international data shows that the following factors should be taken into account in the process of justification of the training model of specialist-organizer of health care:

positions that are assumed in the implementation of health management programs. It is shown that the most in-demand are experts in epidemiology, economics and health management;

educational background. Compulsory basic education, as a rule, is a bachelor's degree of the University;

principles of healthcare managers training, which are based on so-called dual education (medical and non-medical), which is implemented at two levels (basic education and specialization in health management);

educational programs that promote careers of the healthcare managers.

The main attention is paid to the training of practical skills in solving the tasks of the effective management of resources (labor, material, financial) in medical organization.

According to common ideas of international experts on the model of training managers, this model primarily includes innovation, creativity and competence in the field of management. In addition, the manager must demonstrate entrepreneurship, high motivation and responsibility. An ideal manager is a person who looks to the future, manages people by involvement and personal example and strives to the ultimate goal "no matter what" (9). Similar properties are emphasized in the new management model, under which an ideal manager is a responsible person who has the real interest in management and devotes himself/herself to the interests of the organization (10). These characteristics have been proposed by the representatives of the national health service of Finland during the study of the involvement of clinical experts in health system management process (9).

Considering the views of international researchers on various aspects of the competence-based approach in medical education, we note that Griewatz J. et al. (2016) studied the opinion of four professors from German universities on the importance of development of different competences and implementation in the "domestic roles" in the training as the healthcare managers (11). It has been shown that most teachers appreciate the importance of the role of "medical expert", "communicator" and "employee". Other internal roles, such as "health advocate" and "teacher" are less perceived by study participants (11).

Andreasson J. et al. (2016) evaluated the significance of leaders qualities in various sectors of the healthcare system and the importance of the role of different qualities with re- 
spect to improving the process of health care delivery. The surveys of managers in Swedish hospitals were carried out. The central topic of discussion in this case was the so-called "coaching of participation", which is implemented both "vertically" and "horizontally". The latter approach refers to the management strategy for motivating and engaging their employees to the activity for the improvement of the quality of health care. It has been shown that the improvement of health care processes requires a "coaching" management, built on close interactions between a manager and specialists of the individual units, here with managers must share the responsibility for the results with their teams of specialists (12).

Schoenmaker S. et al. (2013) studied the integration of the development of a number of management skills in the frameworks of medical education in Australian medical colleges. In particular, it was shown that the role of a leader is one of the most important competencies of the future doctor, but it attracts too little attention during the training. The aim of the study was to study the perception of managerial skills by young doctors. The survey of 1376 young professionals was carried out in respect to their evaluation of their own needs in the development of manager skills. Most of the respondents assessed the level of their knowledge and management skills as average and pointed to the need for the further development of these knowledge and skills (13).

The aim of the Liang Z. et al. (2013) study was to evaluate the key competencies required for middle and senior managers in public hospitals of both urban and rural areas of Australia. The authors also highlighted 6 key competencies required for training of future managers of health services: management, leadership, organizational behavior, human resource management, strategic planning and financial management (14).

Foreign experts also agree that for the purposes of effective management of diagnostic and treatment processes, in terms of the authors of "Clinical practice guidelines", it is necessary to carry out the justification and development of a model, which would consider the "central role of clinicians in planning, healthcare delivery and the improvment of healthcare quality" $(15,16)$. In recent years, there have been many studies about the characteristics of training and the activity of clinical specialists who hold the management positions in the health care system (17-19).

\section{Literature review}

A number of authors developed an idea of creating an environment in which clinicians could develop their skills and gain the necessary knowledge that would later enable them to become managers. A number of programs are devoted to the study of factors influencing the decision of clinical professionals about moving to leadership positions, including the projects of the European program of cooperation in the field of science and technology "Enhancing the role of clinicians in the management of the European health care system" (20).
In medical institutions of Ireland, the involvement of clinical specialists into the process of health care management is considered a "key factor determining the effectiveness of the medical institution" (21). A series of studies carried out not only in Europe but also in several other countries, including Australia, were dedicated to study characteristics of the governance of medical institutions $(17,22)$.

The concept of involving clinicians in the health management process was met with interest in Norway after the introduction of the unitary management system in 2001. According to the recommendations of the Office of the Auditor General of Norway, clinicians should be more actively involved in the process of making strategic and budgetary decisions to improve the economic efficiency of the health system (23).

The experience of Japanese companies with their high efficiency is also of interest and it shows that it is expensive to conduct management training on the basis of including to the natural traditional method of leaders' development through the official promotion of certain elements inherent in an artificial method that involves extensive target training.

A considerable amount of research is devoted to various aspects of leadership; herewith the leadership is understood as the ability to motivate others to achieve change, while the management is defined as the achievement of results through planning, organization and problem-solving (24-26). Edmonstone J. (2011) designates as the clinical leaders those professionals who are involved in patient care and simultaneously involved in the management process (27). It has been shown that professional dominance and autonomy are the most important motivating factors for the appointment of professionals to managerial positions $(28,29)$.

According to most experts in the field of management training, one of the fundamental functions of a leader is a vision of the future. Also, a creative approach is needed to develop new solutions that can lead the industry or organization to success. Ackoff R., Purdehnad J., (2009) believe that, along with the skills necessary to all administrators and managers, leaders must have the qualities such as credibility, imagination, honesty, cooperation and adaptability (30).

Vision of the future and creative foundation of leadership are closely linked. Individuals who have the creativity potential form the creative class, which includes all of those who are involved in the creation of new forms in any sphere of activity. The system of values of such sort of individuals includes individuality, self-expression, meritocracy and transparency (31).

The foregoing is relevant to the issue of leadership training in medical institutions. As it is known, the health care system in the developed countries is considered a strategically important sector of the economy, which requires adequate regulation and control. In recent years, the process of health care becomes more technologically advanced, being supported by the standardization, implementation of information and communi- 
cation technologies, the use of high-tech methods of diagnosis and treatment. All of these processes contribute to the change of management principles of both a medical organization and the health care system as a whole. A major role in this process must be played by the principles of effective leadership, which, according to some researchers, use all known arsenal of theoretical approaches to leadership, including tvarious theories of leadership (Leader Member Exchange Theory, LMX; Transformational Leadership Theory; Authentic leadership Theory; Servant Leadership Theory; Resonant Leadership Theory) (32).

From the standpoint of the Harvard Business School, the management is an arbitrary (focused) influence on people and their community, which leads to their conscious and active behavior and activity.

The main differences between leadership and management are as follows:

the management provides the organization of the whole group, while the leadership characterizes psychological relations arising in the group "vertically"; that is, from the viewpoint of domination and subordination relations;

the management is a natural and necessary attribute of the emergence of a formal organization, while leadership arises spontaneously as a consequence of the people interactions.

The leader is the subject of group norms and expectations that are formed spontaneously in interpersonal relationships. The successful implementation of the model of "distributed" leadership is possible when two conditions are met: the group is composed of people who are on the same intellectual, cultural and social level, and they have effective communication skills and the bases of behavior of both leader and the subordinate. As a result of this interaction a sense of deeper satisfaction with the achieved results arises. The most successful healthcare organizations consider all of its employees, including all doctors, as potential leaders in the field of their activity (33).

Various countries pay considerable attention to issues of leadership skills development of medical staff. Harvard Business School carries out the educational program "Management of the provision of health services" since 2009. This program is designed for senior-level health care specialists. The program has sparked interest in many countries: only in the first year, 67 people from 16 countries took part in this program. Its main goal is to help professionals in the medical field to form leadership, strategic and financial competences for the improvement of the quality of healthcare $(34,35)$.

According to sociologists, desire of clinicians to be nominated for positions, which involve broad powers, is largely conditional upon the fact that the work of the clinical specialist is constantly associated with struggle against various hindering factors and the overcoming of obstacles. The studies of the activities of clinicians in the healthcare management support this view. For example, Doolin B. (2001) showed that
New Zealand doctors make decision about the managerial position with purposes of some kind of "protection of the clinical practice against intervention on the part of hospital administration" (22).

Forbes T. et al. (2004) carried out a survey of experts in Scotland and found that many doctors have decided to perform the duties of a manager to "protect their profession from influence by unauthorized persons or those they consider as inappropriate persons for the role of the healthcare leader" (36). Similar results were obtained in a survey of experts in Norway $(37,38)$. According to Edmonstone J. (2011), this is largely due to the fact that public health and, in particular, clinical medicine is characterized by the so-called representative, rather than traditional hierarchical management system. The gist of it is that doctors have a responsibility not only in front of governments and higher authorities, but also in front of colleagues who perceive them as representatives of their views and interests (27). Other researchers point out that, though the majority of authors focused on doctors, the same situation can be observed when analyzing the views of other health professionals, such as nurses (9). In particular, Norway is one of the countries where this category of health care workers directly compete with doctors for management positions. According to Johansen and Gjerberg (2009), Norwegian nurses occupy management positions to improve their professional status (38). This fact confirms the sociological theory, according to which the post of the manager is seen as a tool to strengthen the position in the main profession.

\section{Developing characteristics and competences of health care manager}

Despite the all facts regarding the motivation, both cases involve voluntary participation in the process. If the first approach describes the administrative process from the strategic point of view, then, according to the second approach, people hold administrative positions because of the interest in the work and motivation.

In general, the authors agree that the process of development of a doctor as a leader can be divided into three stages: awareness of the leading position, the adoption of the role of the manager and the gaining of experience in this activity. Most of the surveyed executives thought that they were rather persuaded to become managers, while they themselves did not show an active desire for this $(39,40)$.

Certain resemblance to the Russian practice can be traced, in which an entry into the leadership position without the proper level of training to do the job is observed quite often. As reported by foreign participants of the study, they are often forced to learn the principles of management "on the fly", being left to themselves (41).

Some authors describe a situation where doctors became managers by accident $(36,42)$, in terms of foreign researchers, such cases are treated as "the concept of path dependency" and include a scenario in which the doctor accidentally takes a 
control position, and in some cases is "stuck" in this position (42). The individual experts give assent to the higher post purely because of financial reasons and later regret their choice, but the return to the former position is not possible (43). In connection to this, a number of clinicians think that the cessation of clinical activity is certain "point of no return" after the passage of which the doctor does not have other option but to fully devote himself/herself to administrative work (44).

Mo T.D. (2008) compiled a record about Norwegian doctors occupying positions of public health executives and their motivation of administrative activities. Some specialists have reported that they took up a manager position "out of curiosity" (37). Forbes T. et al. (2004) described some of the interviewed experts by the term "investors", because they are actively engaged in administrative work as an alternative to clinical activity (36). However, most of the senior leaders of health care, according to Ham's S. et al. (2011), relate to their work positively (45). The same authors reported problems such as lack of training of doctors for administrative positions: a considerable part of specialists is initially unable to cope with the increased workload. Polls showed that in most of the cases there is a lack of proper organizational support of these specialists, and during the transition to an administrative position, the doctors often do not receive practical advice and assistance (45). According to Ham C. et al. (2011), transition to the administrative position after clinical work is accompanied by a significant change in the conditions of the activity, because a clinical practice in those countries is often routine and standardized, while administrative activities are usually very dynamic. The specialists at the beginning of their leadership activity often feel overwhelmed by that; according to the author, it is a consequence of their inability to delegate some of their work to other specialists (45). Specialists with a longer experience of administrative work reported, as a rule, their ability to effectively organize the work. Herewith, the senior executives, who participated in the study, noted that they learned how to use the experience of other colleagues: "It should be understood that the existing gaps in expertise and experience can be filled by the help of other specialists. Thus, more experienced colleagues can provide the proper level of support" (44).

Kane-Urrabazo C. (2006) noted that the delegation of tasks is one of the main goals of a medical manager (46). Specialists of the UK national health system, after reviewing their own leadership activities, reported a need in increasing the degree of transfer of the functions to other personnel and reduction of the independently performed work (47). These data suggested the need to develop specialists in the field of health care management with the skills of effective delegation of authority.

International experience of training of the management specialists for health care shows that trends in the development of this education include the transition from the programs of medical additional vocational education in public health and health care to the programs based on the management, an increase in the proportion of students with a basic non-medical education, as well as an increase in the number of training programs in the field of public health management in non-medical educational institutions (primarily in economic ones), an increase in the proportion of non-state educational and consulting centers offering the services in the field of advanced professional training for the specialists of healthcare management.

The above trends condition the emergence of new problems, directions and principles of the organization and content of education of the healthcare management professionals, especially, the training of middle and senior executives in accordance with their management level, prior education and personal preferences.

It is well-known that the level of training of medical specialists depends on the university learning technologies. These technologies should be based on the principles of the scientific organization of educational process, structuring the learning objectives, the optimum combination of fundamental and special disciplines, as well as theoretical and practical training. The control of the quality of the learning management, compliance of training programs and characteristics of future specialists are required. In turn, the effective application of the above principles is impossible without the continuous improvement of teaching staff training and provision of an adequate level of university infrastructure.

In the field of educational activities, it is necessary to implement the target orders for training of specialists in accordance with their official functions; the establishment and intensification of interaction between universities and medical organizations, including governance bodies of public health; the development and licensing of the respective programs of additional vocational education; the provision of the opportunities for the high education; the use of modern educational technologies, including those based on IT resources and distance technologies. Training of healthcare management should be based on the principles of continuity of education throughout working life, succession and consistency between the levels and stages of education.

Other authors concluded that involvement of motivated professionals in the leadership positions must be as early as possible $(46,47)$, that will increase the number of prospective candidates for these posts and thus reduce the proportion of individuals who have become managers "by chance" (22). Researchers believe that it is necessary to create a "direct career paths" for healthcare managers with the provision of training opportunities with the aim of eliminating the need observed in practice called "learning on the go".

It is also reported about the need to take into account the experience of organizations, which develop successfully functioning systems for the recruitment and training of potential, such as Mayo Clinic, which creates a support system for novice managers (48). Besides, some authors consider that mentoring is an effective method of training, because early involvement of mentors in the process of training and education 
allows to educate the candidates for the posts of healthcare managers more effectively. As one of such measures, the creation of social networks for the exchange of experience between clinical managers is considered.

It should be noted that some foreign authors $(27,49)$ criticize the set of measures, used in the frameworks of the programs of the national health system for leadership training, and thus believe that the use of competency approach oversimplifies the concept of training of future health care leaders. Edmonstone J. andWestern J. $(2002,2011)$ believe that this approach can only have limited application in the framework of the modern health care system, which is becoming increasingly complex. According to them, an approach based on practical experience is more effective, because it helps in solving a number of problems, which unexpectedly arise in front of health authorities. The authors note that both approaches have their positive and negative characteristics that must be considered (27).

\section{The Academy of Talent Development in Healthcare (ATDH)}

In 2016, in Sechenov University, on the base of the decision of Faculty of Preventive Medicine on Public Health chair the Academy of Talent Development in Healthcare (ATDH) was founded. This project is intended for students of the Sechenov University who have shown an initiative to deepen their knowledge of the discipline "Public Health and Healthcare" andwho want to become leaders in the team and chief physicians of medical organizations.

A special feature of the training is the development of the Academy's corporate culture, which includes the following rules: the main participants in the class are students, teachers act as consultants; attendance is voluntary; mastering of each planned subject and passing the test is an obligatory condition of education; any sensible initiative in learning is welcomed; to get the result you need to work hard and stand on the shoulders of giants, respect the environment and the experience of your predecessors. This approach allows us to create high professionalism, innovative thinking, creative mentality, modern worldview culture and high social responsibility among specialists.

During the out-of-class time, which is part of student selfmanagement, the teaching staff of the department conducts individual consultations on the successful accomplishment of tasks in the student council, the unions of students, the volunteer center, the student sports camp "Sechenovets", among schoolchildren, scientific societies, etc.

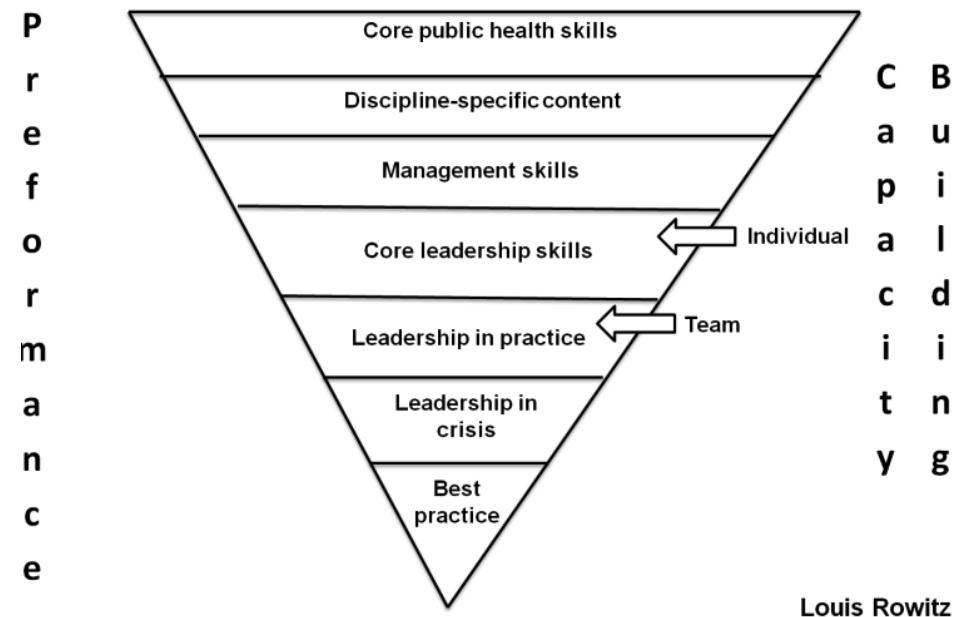

Figure 1: The leadership pyramid is the core idea of teaching program in The Academy of Talent Development in Healthcare

Each level of the pyramid requires a determination of the specific competencies necessary to master. Building capacity is divided into individual Competency and Team competency. Public Health professionals improve their skills by training in Core public health disciplines, Discipline - specific content, in Management module, PH workforce and Leadership.

Public Health professionals increased their personal skills, which can then be translated into team-based and other collaborative processes. The bottom of the pyramid emphasizes the importance of best practices.
We use modern didactic concept, which includes developmental teaching and problem-based learning, selfeducation, creative activity of students, communication training with professional activity, interactive learning and flexibility in solving the problems. Professors and teachers use active learning methods: work in small groups, business games, role play, case study and others.

Case studies are very important in training healthcare managers. They give an opportunity to simulate real situations from the routine of healthcare management. We use case studies for undergraduate and master students as well as for those 
who take part in the Academy of Talent Development in Healthcare. The case studies are combined in a practical module "innovation in HC management" "«, which covers 10 topics, including: effective HC manager, sharing of powers and responsibilities, complex decision making, development of the image and culture of $\mathrm{HC}$ organization.

One year ago we have initiated a research project aimed at early detection of students with a strong potential in management and promotion of the competences necessary for successful career in healthcare management. We enrolled 200 volunteers and randomized them into study and control groups. Enrollment criteria included:

1. Study for $4-6$ years

2. Extracurricular activities

3. Strong motivation for success

4. Good communication skills

5. Adaptability

Both groups are currently being assessed on psychophysiological characteristics and leadership abilities.

Currently, there is ongoing research in individual approaches to training healthcare managers. Its main objective is to develop a pattern for individual curriculum and early career development for students with strong leadership capacities.

The primary outcome is an educational model for Health care manager training aiming at leadership competences development based on individual educational path.

The secondary outcomes include:

1. Detection of correlation between personal and psychophysiology characteristics that will give an opportunity to create a system of criteria aiming at potential Health care manager identification.

2. Development of a program of vocational route for higher education system for a competitive Public health specialist training.

3. Development of "The Academy of Talent Development in Healthcare"» with the aim of vector training of public health managers, for residency pre-training.

4. Implementation of database containing social, psychophysiological, demographical and personal characteristics of potential HealthCare leaders.

We also used physiological study to measure the adaptive capacity by EEG and ECG results. To assess the switching and distribution of attention, we used Red-black SchulteGorbov tables under EEG. We also evaluated "Intellectual lability" by assessing the ability of a subject to switch attention, multiple problem solving with no mistakes, etc.
We reviewed literature to identify physiological parameters present in people with strong managerial skills.

To assess the personal characteristics we used survey data via the use of personality tests: "leadership style test" (P. Hersey and K. Blanchard) and "Self-limitation analysis" (M. Woodcock and D. Francis). We assume that these questionnaires will help assess the readiness of young specialist to work in the field of health management.

We also used sociological methods to assess the impact of social factors and health status on leadership characteristics development.

\section{Future perspectives}

\section{Future perspectives in development of public health care system are the following:}

To identify and compare most significant social, psychophysiological and personal characteristics of students, residents and professionals in the field of Public Health and Medical Care Organization, which will help to collect data on social, psychophysiological, social-psychological characteristics and health status of students at different years of medical training at university.

To justify the system of socio-psychological and psychophysiological criteria of professionals in the field of Public Health and Medical Care Organization, with the aim of creation of Student's career guidance program defining the vector of training in a particular specialty.

To develop a flexible specialist training model in the field of Public Health and Medical Care Organization, including the design and implementation of individual educational routes, using modern educational methods. We believe that detection of correlation between psycho-physiological characteristics and leadership competences will give an opportunity to create a system of criteria aiming at potential HealthCare leaders' identification. This methods can be used in early stages of students training. The introduction of early identification of students with leadership characteristics will enable to create individual educational paths for such students, increase the effectiveness of career guidance and selection to continue the training in residency and create conditions for more efficient use of human resources.

\section{CONCLUSION}

Human resources development is the most important problem of the public health in Russia. At the same time, Russian public health is dynamic; it is characterized by rapid structural and functional changes. This increases the demands for economic methods in management. The demand for professionals with skills to manage healthcare organizations at various levels of the public health system is significantly increasing. The role of professionals competent in the strategic management methods increases. Given the urgency of the various aspects of the implementation of competency-based approach, 
we believe that the education and training of future healthcare organizers, based on the development of key competences, is of special interest. In light of this, the review of international data on organization of key competence development is important. Herewith it is necessary to take into account the educational content, resources and technologies, the determination of the factors that influence this process, the development and evaluation of models aimed at improvement of the education of healthcare management professionals at medical schools.

We believe that the results of such analysis will help to develop and offer a number of practical measures aimed at improving education and training of healthcare management experts in the Russian higher education and ultimately enhance the effectiveness of the Russian health care organizations.

\section{ACKNOWLEDGMENTS}

We express our gratitude towards the Faculty of Preventive Medicine, Sechenov University, Russia, for supporting the Academy of Talent Development in Healthcare. We are also grateful to Russian Academic Excellence Project 5-100 for providing opportunities concerning project implementation.

\section{REFERENCES}

1. Odinayev F.I., Dzhabarova T.S., Khodzhaev F.M. On the issue of optimizing the studding of management personnel in the health care system during the reform period // Bulletin of the Tajik National University. A series of socio-economic and social sciences. - 2015. - No. 2-6 (175) - P. 62-68.

2. Perepelkina N.Y., Pavlovskaya O.G., Kalinina E.A. and others. The results of ten years of experience in the tenyear training of doctors on the specialty "Organization of Public Health and Public Health" // Ural Medical Journal. - 2014. - No. 6 (120). - P. 85-87.

3. Bashmakov O.A. Perfection of the system of training of leading cadres of public health // Social aspects of public health. - 2015. - No. 1 - C 41.

4. Smagina O.A. Theoretical aspects of professionalpersonal development of future specialists in medical profile // Bulletin of Saratov State Technical University. 2012. - T. 1, No. 1 (63). - P. 212-215.

5. Ilyin A.S. Actual problems of professional and educational activity of organizers of public health in rural areas // Human Capital. - 2012. - No. 7 (43). - P. 39-43.

6. Kulbakh O.S. ,Zavarzina N.Y., Zinkevich E.R. Competence approach as a basis for designing the content of the curriculum / / Bulletin of the Volzhsky University. V.N. Tatishchev. - 2015. - No. 2 (18). - P. 106-113.

7. Andersson H., Sundstrom B.W., Nilsson K., JakobssonUng E. Competencies in Swedish emergency departments - The practitioners' and managers' perspective // Int. Emerg. Nurs. - 2014. - Vol.22 (2). - P.81-87.

8. Ovsyanitskaya L.Y. Theoretic-methodological bases of development of information competence of experts of system of public health services. - M .: Perot, 2015. - 163 p.

9. Viitanen E., Konu A. Leadership style profiles of middle managers // Leadersh Health Serv. - 2009. - Vol.22 (2). P.108-120.

10. Lapsley I. The NPM agenda: back to the future // Financial Accountability \& Management. - 2008. - Vol. 24(1). - P.77-96.
11. Griewatz J., Wiechers S., Ben-Karacobanim H., Lammerding-Koeppel M. Medical teachers' perception of professional roles in the framework of the German National Competence-Based Learning Objectives for Undergraduate Medical Education (NKLM)-A multicenter study // Med. Teach. - 2016. - Apr 13:1-9. (Epub ahead of print)

12. Andreasson J., Eriksson A., Dellve L. Health care managers' views on and approaches to implementing models for improving care processes // J. NursManag. - 2016. Vol.24 (2). - P.219-227.

13. Schoenmaker S.G., Berkenbosch L., Ahern S., Busari J.O. Victorian junior doctors' perception of their competency and training needs in healthcare management // Aust. Health Rev. - 2013. - Vol.37(4). - P.412-417.

14. Liang Z., Leggat S.G., Howard P.F., Koh L. What makes a hospital manager competent at the middle and senior levels? // Aust. Health Rev. - 2013. - Vol.37 (5). - P.566573.

15. Gray A., Harrison S. Governing medicine: theory and practice. - Buckingham: Open University Press, 2004.

16. Degeling P.J., Maxwell S., Iedema R., Hunter D.J. Making clinical governance work // BMJ. - 2004. - Vol.329 (7467). - P.679-681.

17. Fulop L., Day G.E. From leaders to leadership: clinician managers and where to next? // Aust. Health Rev. - 2010. - Vol.34 (3). - P.344-351.

18. Goodall A.H. Physician-Leaders and Hospital Performance: Is There an Association? // Soc. Sci Med. - 2011. - Vol.73 (4). - P.535-539.

19. Cragg R., Marsden N., Wall D. Perceptions of the Clinical Director Role // Br. J. Healthc. Manag. - 2008. Vol.14 (2). - P.58-65.

20. NHS Institute for Innovation and Improvement: clinical leadership competency framework project. (http://www.institute.nhs.uk/ building_capability/building_leadership_capability/clinical_ leadership_competency_framework_project.html). 
21. McDermott R., Callanan I., Buttimer A. Involving Irish clinicians in hospital management roles -towards a functional integration model//Clinician Manag.-2002.-Vol. 11(1).-P.37-46.

22. Doolin B. Doctors as managers: new public management in a New Zealand hospital//Public.Manag.Rev.-2001.Vol.3(2).-P.231-254.

23. Fernandez-Aros K. The choice of the strongest: how the leader to make the main decisions about people / Trans. with English. - M.: Mann, Ivanov and Ferber, 2013. - 408 p.

24. Asante A., Roberts G., Hall J. Are view of health leadership and management capacity in the Solomon Islands//Pac. Health Dialog.-2012.-Vol.18(1).-P.166-177.

25. YarbroughLandry A., Stowe M., Haefner J. Competency assessment and development among health-care leaders: results of a cross-sectional survey//HealthServ.ManageRes.-2012.-Vol.25(2).-P.78-86.

26. Edmonstone J. The challenge of capability in leadership development//Br.J. Health Care Manage.-2011.Vol.17(12).-P.572-578.

27. Bongiovanni T., Long T., Khan A.M., Siegel M.D. Bringing Specialties Together: The Power of Intra-Professional Teams//J. Grad. Med. Educ.-2015.-Vol.7(1).-P.19-20.

28. Freidson E. Professionalism: the third logic.Cambridge:PolityPress, 2001.

29. Akoff R.L., Purdekhnad J. It is useful to distinguish between manager and leader // Problems of management in social systems. - 2009. - Vol. 1, Vol. 1. - P. 92-94.

30. Flori-

daR.TheCreativeClassandEconomicDevelopment//Econo mic Development Quarterly.-2014.-Vol.28,Issue3.P.196-205.

31. Wong C.A., Cummings G.G., DucharmeL.The relationship between nursing leadership and patient outcomes: a systematic review update//Journal of Nursing Management.-2013.-Vol.21,№5.-P.709-724.

32. Mountford J.,Webb C. When clinicians lead.TheMcKinseyQuarterly,2009.

33. Busari J.O. Management and leadership development in healthcare and the challenges facing physician managers in clinical practice//The International Journal of Clinical Leadership.-2013.-Vol.17(4).-P.211-216.

34. Carter K., Chalouhi E., McKenna S., Richardson B.What it takes to make integrated care work//Health International.-2011.-Vol.11.-P.48-55.

35. Forbes T., Hallier J., Kelly L. Doctors as managers:investors and reluctants in adual role// HealthServ.ManageRes.-2004.-Vol.17(3).-P.167-176.
36. MoTO: Doctors as managers: moving towards general management?//J. Health Organ.Manag.-2008.Vol.22(4).-P.400-415.

37. Johansen M.S., Gjerberg E. Unitary management, multiple practices?//J.HealthOrgan.Manag.-2009.Vol.23(4).-P.396-410.

38. BradleyH., Lehmann U., Butler N. Emerging roles and competencies of district and sub-district pharmacists: a case study from CapeTown//Hum.Resour.Health.-2015.Vol.24;13:88.

39. DickinsonH., Ham C. Engaging doctors in leadership: review of the literature.-Birmingham:Health Services Management Centre,University of Birmingham,2008.

40. Kirkpatrick I., Jespersen P.K., Dent M., Neogy I. Medicine and management in a comparative perspective: the case of Denmark and England//Sociol.Health.-2009.Vol.31(5).-P.642-658.

41. Boucher C. J. Tobeornottobe. A manager: the career choices of health professionals//Aust.HealthRev.-2005.Vol.29(2).-P.218-225.

42. DrummondH., ChellE. Life' schances and choices:a study of entrapment in career decisions with reference to Becker's side bets theory//PersRev.-2001.-Vol.30(2).-P.186202.

43. HoffT .J. The social organization of physician-managers in a changing HMO//WorkOccup.-1999.-Vol.26(3).P.324-351.

44. Ham C., Clark J. ,Spurgeon P.et al.D octors who become chief executives in the NHS: from keenamateur stosk illed professionals //J.RoySoc.Med.-2011.-Vol.104(3).P.113-119.

45. Kane-Urrabazo C. Management's role in shaping organizational culture//J. Nurs. Manag.-2006.-Vol.14(3).P.188-194.

46. Woolnough H.,Faugier J. An evaluative study assessing the impact of the Leadingan Empowered Organisation//Nurs Times Res.-2002.-Vol.7(6).-P.412-427.

47. Berry L., Seltman K. Management Lessons from Mayo Clinic: Inside One of the World's Most Admired Service Organizations.-NewYork.NY:McGraw-Hill,2008.

48. Bolden R., Gosling J. Leadership competencies: time to change the tune?//Leadership.-2006.-Vol.2(2).-P.147163.

49. Reshetnikov V., Korchever N., Dorovskaya A. Regularities of career growth of doctors in medical organizations // Siberian medical review.- 2015. - Vol. 4(4). - P.61-66. 